\title{
KEWENANGAN DEKONSENTRASI DALAM PENYELENGGARAAN OTONOMI DAERAH DAN PERMASALAHAN PENYELENGGARAANYA* DI DAERAH
}

\author{
Oleh : Tim PKP2A III LAN
}

\begin{abstract}
Governance management framework in autonomy framework relies on 3 especial principal, decentralization, dekonsentrasi anda medebewind (Tugas

Pembantuan). In the united state corridor, dekonsentrasi and decentralization dekonsentrasi and decentralization cannot be dichotomized, both have to fill and strengthen each other. Dekonsentrasi is often said have strategic function to unify the Republic of Indonesia. Unfortunately, the regulation of dekonsentrasi management is still the minimum grade. This condition has been appropriately generating many problems so that central government have to give serious attention through releasing regulation or policy in synergizing function, institution and programs in dekonsentrasi management so that it can walk as its goals.
\end{abstract}

Key words : Desentralisasi, Dekonsentrasi

\section{Pendahuluan}

Sebagai implikasi logis dari berlakunya kerangka kebijakan desentralisasi yang baru, kewenangan dan urusan pemerintah daerah (khususnya kabupaten/kota) semakin luas sedangkan kewenangan dan urusan unsur pemerintah pusat semakin mengecil. Meskipun demikian, demi mempertahankan eksistensi, integritas dan "hak kedaulatan" suatu negara bangsa (nation-state), maka pemerintah pusat masih memiliki hak-hak tertentu di daerah, atau dapat melakukan intervensi dalam bentuk supervisi, pembinaan, pengawasan, dan penilaian kinerja otonomi di daerah. Hak "intervensi" Pusat atas Daerah ini dapat dijalankan secara langsung oleh instansi tingkat Pusat (departemen/ LPND), maupun secara tidak langsung melalui aparatnya di daerah yakni Gubernur.

Secara idealistik, gagasan besar desentralisasi pasca tumbangnya rezim Orde Baru memang sangat bagus. Namun dalam tataran implementasi, masih banyak yang perlu dibenahi kembali. Hal ini antara lain tercermin dari berbagai kritik dan koreksi yang banyak diberikan oleh para pakar sehubungan dengan diberlakukannya UU No. 32 Tahun 2004 tentang Penyelenggaraan Pemerintahan Daerah. Diantara para pakar tadi adalah dari Prof Dr. Miftah Thoha, Guru Besar Universitas Gajah Mada yang menyebutnya undang-undang tersebut menebarkan "aroma sentralistik" selain dipandang menyiratkan adanya keinginan untuk kembali sebagaimana masa pemerintahan Orde Baru, yakni pemerintahan yang kuat, efektif dan dapat dikendalikan dari sentral.

Demikian halnya dengan Profesor Ryaas Rasyid yang juga beropini bahwa undangundang tersebut menarik empat kewenangan penting kembali ke atas, yakni pengangkatan sekretaris wilayah daerah (sekwilda), pengesahan peraturan daerah, pengaturan kecamatan, desa/kelurahan dan rekrutmen pegawai negeri sipil (PNS). Keempat penarikan kewenangan tersebut mengindikasikan adanya kemauan politik yang mengarah pada sentralistik. Demikian halnya dengan pandangan Dr. Syarif Hidayat yang juga mencermati kewenangan

\footnotetext{
" Tulisan ini merupakan saduran dari hasil penelitian PKP2A III LAN Samarinda Tahun 2007 dengan Judul "Kajian Tentang Evaluasi Kinerja Pemerintah Propinsi dalam Penyelenggaraan Kewenangan Dekonsentrasi"
} 
dekonsentrasi kini menunjukkan kemunduran, di mana pada UU No 22 Tahun 1999, dekonsentrasi sudah mulai dikurangi, maka pada UU No 32 Tahun 2004, justru dekonsentrasi kembali dihidupkan.

Pada sisi lain, Ketua Fraksi II DPR RI Ferry Mursidan Baldan secara politis memberi tanggapan balik, bahwa: "UU No. 32/2004 tidak perlu ditafsirkan bernuansa sentralistik. Kalaupun ada, sentralisasi itu berlaku pada nasib pegawai negeri sipil (PNS) agar jenjang karier mereka dapat berkembang. Selain itu didasarkan undang-undang tersebut muncul sebagai respon atas berbagai kekhawatiran akan munculnya fanatisme kedaerahan (etnosentrisme) yang justru akan mengancam persatuan dan kesatuan bangsa".

Berbagai perhelatan pandangan dan opini tersebut menunjukan, bahwa kewenangan desentralisasi pemerintah (Pusat) dikritisi dan dipertimbangan untung ruginya dalam penguatan kapasitas pemerintahan di daerah. Sebagaimana dipahami, undang-undang sebelumnya telah menjadikan pengurangan dan penghapusan sejumlah kantor departemen di kabupaten/kota dan sebagian kantor wilayah di provinsi. Perhelatan ini sekaligus menjadikan status kewenangan dekonsentrasi pada UU No. 32 Tahun 2004 harus diperjelas dan dirunkan dalam bentuk kebijakan yang lebih operasional.

Desentralisasi yang dimaknai sebagai "penyerahan" sebagian wewenang memang telah berjelintang dengan tugas dan wewenang pusat dalam bentuk dekonsentrasi atau "pelimpahan" sebagian wewenang dari pemerintah pusat kepada pemerintah daerah (khususnya kabupaten/kota), selain juga tugas pembantuan. Penguatan peran pemerintah pusat dengan dekonsentrasi memang secara implisit bukan sekedar menambah peran yang sebelumnya mengecil, melainkan lebih jauh dilandasi oleh pemikiran ke depan yakni menjaga kedaulatan suatu negara bangsa (nation-state). Untuk itu perundangan tersebut memberikan landasan bahwa pemerintah pusat berhak melakukan intervensi dalam bentuk supervisi, pembinaan, pengawasan, dan penilaian kinerja otonomi pada pemerintahan daerah. Hak Pemerintah Pusat dijalankan secara langsung oleh instansi tingkat Pusat (departemen/ LPND), maupun tidak langsung dengan pelimpahan wewenang melalui aparatnya yang ada di daerah yaitu pejabat Gubernur.

Posisi Pemerintah Provinsi dalam koridor otonomi daerah memiliki 2 (dua) kedudukan, yakni sebagai wakil pemerintah pusat dengan menjadikan aparat dekonsentrasi, dan sekaligus juga menjadi pelaksana otonomi daerah itu sendiri atau aparat desentralisasi. Sementara kabupaten/kota diposisikan tidak lagi memiliki fungsi yang inheren dengan fungsi dekonsentrasi.

Fungsi Pemerintah Provinsi dengan Gubernur-nya sebagai aparat dekonsentrasi (baca: Wakil Pemerintah), pada dasarnya berfungsi sebagai unit penghubung (intermediate administrative entity) antara Pusat dan Daerah (Kabupaten/Kota). Posisi yang intermediasi ini menjadikan Pemerintah Provinsi menjalankan dua tugas, yaitu sebagai "agen tunggal" dalam menjabarkan berbagai kebijakan Pemerintah Pusat yang menyangkut urusan kepemerintahan daerah, dan juga sebagai "agen tunggal" dalam menyediakan seluruh informasi tentang keadaan Pemerintah Daerah kepada Pemerintah Pusat (Schiavo-Campo dan Sundaram, dalam To Serve and To Preserve: Improving Public Administration In A Competitive World, 2000).

Dengan landasan undang-undang Nomor 32/2004 tersebut mestinya Pemerintah Provinsi benar-benar berfungsi sebagai intermediasi tersebut. Namun dalam kenyataan, penyelenggaraan dekonsentrasi juga telah menjadikan efek loncatan katak (leapfrogging effect), dengan transfer kewenangan dan sumberdaya Pusat yang langsung diterima oleh Pemerintah Kabupaten/Kota. Pada sisi yang lain, telah terjadi pula transfer sebagian kewenangan dan sumberdaya dari Pemerintah Pusat ke Pemerintah Provinsi yang harus diturunkan kepada pemerintah Kabupaten/Kota. Penyelenggaraan dekonsentrasi inilah yang menjadikan fenomena persoalan di lapangan menjadi krusial. Untuk itu, fungsi dekonsentrasi yang diselenggarakan oleh pemerintah provinsi menjadi faktor kunci dalam sukses atau gagalnya suatu implementasi desentralisasi politik yang telah dilaksanakan dengan seluasluasnya (devolution) tersebut di tingkat pemerintah kabupaten/kota. 
Pengalaman di tingkat internasional membuktikan, bahwa pelaksanaan desentralisasi yang sifatnya "kebablasan" telah memberi dampak sosial ekonomi yang merugikan bagi sebagian besar masyarakat daerah. Hasil penelitian Mark Turner (2002, dalam Public Administration and Development Journal, No. 22, www.interscience.wiley.com) justru menunjukkan, bahwa pelaksanaan dekonsentrasi pada Bangsa Kamboja telah memberi manfaat yang bervariasi. Sementara desentralisasi cenderung dipandang gagal dapat memenuhi harapan yang ditetapkan sebelumnya.

Berdasarkan pengalaman itu menjadi bertambah penting untuk menguatkan peran Pemerintah Provinsi dalam konteks pelaksanaan fungsi dekonsentrasi dalam kebijakan otonomi daerah. Kepentingan tersebut diterawang bukan hanya sekedar "perekat" antara kepentingan nasional dengan kepentingan daerah, namun lebih jauh lagi menjadi jaminan keterlaksanaan penyelenggaraan pemerintahan dalam bidang pembangunan dan pelayanan yang dapat berjalan secara efektif dan efisien.

\section{Fungsi Dekonsentrasi Dalam Kerangka Sistem Desentralisasi Negara Kesatuan}

Konsep desentralisasi diartikan secara sempit maupun meluas. Desentralisasi dalam arti sempit sebagai penyebaran kewenangan secara vertikal, yakni dari pusat kepada bagian yang ada di bawahnya. Pusat adalah pemegang kewenangan tertinggi dan terluas yang disebarkan kepada struktur dibawahnya. Berbeda dengan desentralisasi dalam arti luas, dimana penyebaran wewenamh tidak hanya vertical melainkan juga horizontal, dimana penyebaran bukan saja dari struktur tinggi ke bawah, melainkan antarorgan yang ada dalam kawasan struktur pusat, baik yang ada berada di wilayah pusat maupun di wilayah yang lebih bawah. Bahkan lebih dari itu terjadi penyebaran wewenang dari pusat struktur kepada kelompok masyarakat.

Dalam konteks Pemerintahan di Indonesia, pengertian desentralisasi, baik dalam arti yang sempit ataupun luas termuat dalam peraturan perundangan nomor 32/2004 tentang Pemerintahan Daerah. Perundangan tersebut mengatur penyebaran kewenangan tidak hanya bersifat vertikal berupa penyerahan sebagian wewenang dari pemerintah pusat kepada pemerintah daerah, melainkan mengatur penyebaran secara horizontal, yaitu pelimpahan sebagian wewenang dari pemerintah pusat kepada internal organ pemerintah pusat lainnya yang berada di wilayah daerah. Kebanyakan desentralisasi di Indonesia diartikan sempit, yakni sebagai penyebaran atau transfer wewenang (transfer kekuasaan) dari pemerintah pusat kepada pemerintah daerah. Sedangkan desentralisasi yang merupakan penyebaran, atau pelimpahan sebagian wewenang (transfer kekuasaan) dari pemerintah pusat kepada otoritas lain yang bersifat spesial dan legal personal kurang populer. Padahal proses penyebaran tersebut juga mengikutkan pelimpahan tugas-tugas, sumber daya dan kekuatan politik kepada lembaga yang ada region tertentu bahkan kepada komunitas masyarakat yang dilakukan secara kooperatif (Marz, 2001: 2).

Secara teoritik Van Der Pot (dalam Manan 1994: 21) mengemukakan, desentralisasi dapat dibedakan ke dalam dua bagian, yakni: 1). Desentralisasi teritorial yang berupa pembentukan dan pengoperasian badan-badan yang didasarkan atas kewilayahan dan; 2) desentralisasi fungsional, yang berupa pembentukan dan pengoperasian badan-badan yang didasarkan atas tujuan-tujuan tertentu. Pembedaan jenis desentralisasi teritorial dan desentralisasi fungsional tidak mengubah makna secara mendasar, yakni pelimpahan wewenang. Berbeda dengan Irawan Soejipto mencoba membalah ke dalam tiga bagian, yakni menjadi: 1) Desentralisasi teritorial; 2) Desentralisasi fungsional; dan 3) Desentralisasi administratif. Ahli lain adalah, Amrah Muslimin (1978: 15) yang juga membedakan desentralisasi menjadi tiga bagian, yakni: 1) Desentralisasi politik; 2) Desentralisasi fungsional; dan 3) Desentralisasi kebudayaan. Desentralisasi politik memiliki kemiripan dengan desentralisasi teritorial. Desentralisasi fungsional maknanya hampir sama dengan yang dimasud oleh Van Der Pot. Sementara desentralisasi kebudayaan dipahami sebagai pemberian hak kepada golongan minoritas dalam upaya penyelenggaraan kebudayaan 
lingkungan sendiri.

Pengkategorian desentralisasi yang banyak dirujuk oleh para ahli yang dikemukakan Cheema dan Rondinelli (1983: 18-25). Dikemukakannya, bahwa desentralisasi dapat dibedakan menjadi empat kategori, yakni: 1) Delegation to semi autonomous or parastatal organization; 2) Devolution; 3) Transfer of function from government to nongovernment Institution; dan 4) Dekonsentrasi.

Desentralisasi sebagai delegation to semi autonomous or Parastatal Organization, yaitu pendelegasian pengambilan keputusan dan kewenangan manajemen untuk menjalankan fungsi-fungsi tertentu kepada organisasi yang tidak secara langsung berada di bawah pengawasan pemerintah pusat. Dalam desentralisasi dengan pendelegasian semi otonom terjadi proses transfer pembuatan keputusan pemerintah yang harus dilakukan secara hati-hati penjabarannya oleh institusi atau organisasi yang posisinya berada di bawah kontrol tidak langsung dari pemerintah (UNDP, 1999: 7). Pendelegasian tiada lain merupakan transfer responsibili berkenaan dengan kebijakan-kebijakan yang diberikan kepada pemerintah daerah yang bersifat semi otonom, namun tetap harus bertanggung jawab kepada pemerintah pusat (Schneider, 2003: 12). Pendelegasian tersebut berupa kebijakan mewajibkan pemerintah daerah menciptakan perusahan publik, institusi perumahan, transportasi, pelayanan spesial kecamatan semi sekolah otonom badan perusahan daerah atau unit proyek-proyek khusus (Litvack and Seddon, 1998: 3).

Kategori desentralisasi sebagai devolution yang dimaknai upaya pembentukan dan juga penguatan unit-unit organisasi secara independen. Cheema dan Rondinelli (1983: 22) menyatakan karakteristik devolusi adalah pemerintah daerah yang memiliki status otonom, bersifat independen atau terpisah dari pemerintah pusat, sehingga kewenangan pusat terhadap pemerintah daerah relatif menjadi kecil dan juga ditandai dengan tidak adanya pengawasan pemerintah pusat secara langsung kepada pemerintah daerah. Pemerintah daerah yang dimaksud memiliki batas geografis yang jelas dan bersifat legal dalam menyelenggarakan kewenangannya dan juga dapat melaksanakan fungsi kepemerintahan dengan sendirinya. Dalam hal ini pemerintah daerah tersebut memiliki kekuasaan untuk melindungi sumbersumber yang sekaligus dapat memelihara fungsi-fungsi pemerintahannya. Dalam kaitan itu, devolusi juga memiliki kaitan dengan kebutuhan pengembangan kelembagaan pemerintah daerah dalam bentuk institusi-institusi yang diperankan sebagai pemenuh kebutuhan masyarakat dengan cara pemberi pelayanan secara memuaskan. Namun demikian, desentralisasi melalui devolusi juga mengharuskan adanya hubungan yang bersifat timbal balik atau saling menguntungkan dengan cara memelihara hubungan koordinatif antara pemerintah pusat dan pemerintah daerah.

Kategori pemaknaan desentralisasi sebagai transfer of function from government to non-government institution. Kategori desentralisasi ini adalah transfer beberapa jenis bidang perencanaan dan juga tanggungjawab yang bersifat administratif yang berkaitan dengan fungsi-fungsi publik dari pemerintah pusat kepada LSM, organisasi swasta atau organisasi non pemerintah. Kategori desentralisasi ini dapat disejajarkan dengan kebijakan debirokratisasi. Transfer fungsi publik kepada non-pemerintah hanya bisa berlangsung dalam kehidupan masyarakat yang demokratis, yang ditandai dengan pelimpahan sektor-sektor yang berkaitan dengan pemasukan keuangan ataupun yang bersifat administratif kepada lembagalembaga volunteer, atau lembaga swasta atau institusi non-pemerintah lainnya seperti organisasi hybrid, diantaranya asosiasi industri dan perdagangan, asosiasi profesi, dll. Bahkan lebih jauhnya pemerintah dapat saja menyerahkan tugas dan kewajibannya pada organisasi non-pemerintah untuk memproduksi barang maupun jasa layanan yang sering disebut juga privatisasi.

Kategori pemaknaan desentralisasi keempat adalah deconcentration. Dekonsentrasi dimaknai sebagai proses redistribusi tanggungjawab yang bersifat administratif untuk diberikan kepada institusi yang berada dalam sayap pemerintah pusat. Institusi tersebut diwujudkan dalam dengan cara pembentukan dan pengoperasionalan berbagai kantor atau 
institusi pusat yang ditempatkan pada berbagai wilayah atau lembaga pemerintah lain yang dibawahnya yang diatur dan ditetapkan melalui perundangan.

Berkaitan dengan keempat kategori desentralisasi yang berbeda-beda, maka Morrison (2004) memvisualisasikan hubungan antara sentralisasi, desentralisasi dan dekonsentrasi dalam sebuah sprektum yang menjelaskan bahwa perubahan struktur pemerintahan dapat berlangsung dalam dua arah, yakni arah kanan yang menandai penyebaran atau desentralisasi dan bisa juga arah ke sebelah kiri dari titik sentralisasi menjadikan pelimpahan wewenang pusat atau dekonsentrasi. Spectrum tadi memperlihatkan adanya arah yang berlawanan secara diametral yang tidak memungkinkan keduanya bisa bertemu. Akan tetapi, sesungguhnya kedua arah tersebut bisa dipersatukan dengan posisi sentral (pusat) yang harus terjaga, sehingga menyerupai bandul jarum jam tembok yang mengayun ke kiri dan kemudian mengayun kekanan.

Dalam konteks perubahan struktur pemerintahan, khususnya di negara berkembang pola perubahan bisa berlangsung cepat, manakala struktur yang ada tidak menampakkan adanya keteraturan atau keseimbangan fungsi dari masing-masing struktur yang ada. Keteraturan tersebut ditandai dengan tetap kokoh dan kesatuan pemerintahan suatu wilayah negara. Atau dengan kata lain, pilihan untuk desentralisasi atau dekonsentrasi pada dan atau bahkan keduanya senantiasa terikat dengan keteraturan pemerintahan suatu bangsa. Pola pemerintahan yang bersifat dekonsentrasi adalah pola dan struktur pemerintahan yang selama ini kekuasannya digenggam kemudian dilimpahkan kepada lembaga atau badan dan juga kepala pemerintah administratif yang terpercaya, dan kewenangan tersebut sifatnya terbatas untuk menjadi perpanjangan tangan dari pemerintah pusat (UNDP, 1999: 17).

\section{Kewenangan Dekonsentrasi}

\section{Konsep Dekonsentrasi}

Sebagai bagian dari tranfer wewenang tidak dipandang sebagai bagian dari makna desentralisasi dalam arti yang luas. Dekonsentrasi sebaliknya diasosiasikan sebagai kebalikan dari desentralisasi dalam arti devolusi karena lebih menekankan pada distribusi kekuasaan pusat yang memperkuat dan menstabilkan kekuasaan pusat di daerah. Kebijakan ini dipandang tidak popular di Indonesia sejak reformasi di gulirkan pasca krisis, selain juga pengalaman-pengalaman masa lalu yang tidak menyenangkan ketika Orde baru berkuasa. Ketika dekonsentrasi digulirkan bersamaan dengan desentralisasi dan tugas perbantuan dalam UU nomor 32/2004, maka dapat dipahami bilamana mengundang banyak opini. Dalam Undang-undang tersebut dekonsentrasi menjadi salah satu pilar yang dimaksudkan untuk belangsungnya keseimbangan dalam struktur pemerintahan di Indonesia, khususnya dalam kesatuan dan persatuan dalam wilayah Republik Indonesia.

Bagi Dore dan Woodhill (1999: 16) dekonsentrasi dipandang sebagai proses kepemerintahan yang dilakukan dengan cara menciptakan daerah-daerah administratif untuk tujuan efisiensi manajemen program. Implementasi dekonsentrasi diberikan atau diturunkan, baik secara luas ataupun terbatas dari pemerintah pusat kepada regional manager yang ditempatkan pada suatu daerah. Selain itu dekonsentrasi juga melibatkan transfer kewenangan yang sifatnya terbatas dalam hal pengambilan keputusan yang spesifik dan manajemen fungsional dengan cara-cara administratif kepada level organisasi yang berbeda, namun demikian tetap berada di bawah kewenangan yuridis yang sama dari pemerintah pusat (UNDP, 1999: 17). Karena itu dekonsentrasi sering dianggap pula pseudo desentralisasi atau desentralisasi yang tidak sebenarnya, karena tidak mengandung dan menjalankan kebijakan yang sifatnya substansi lokal dalam pengambilan keputusan (Fesler, 1969, dan Morrison, 2004).

Munculnya konsep dekonsentrasi dilakukan ketika terjadi peningkatan fungsi dan aktivitas pemerintahan yang memperlihatkan adanya gejala kesenjangan (gap) yang kian hari kian melebar antara pemerintah pusat dan daerah. Dekonsentrasi muncul terhadap kebutuhan publik untuk berinteraksi secara intensif dengan pemerintah pusat. 
Kemunculan dekonsentrasi ditandai dengan dibentuk dan diperasionalkannya sejumlah kantor-kantor parlemen dan pemerintah yang berada di luar ibukota (Asia Researh Centre, 2001).

Makna dekonsentrasi sendiri oleh Cheema dan Rondinelli (1983 18 - 25) sebagai redistribusi tanggungjawab administratif yang diberikan di antara lembaga pemerintah pusat. Lembaga pemerintah tersebut adalah kantor-kantor perwakilan yang berada di setiap wilayah daerah. Redistribusi tersebut bisa berupa field administration; dan atau local administration.

Field administration, adalah penempatkan kantor-kantor pemerintah pusat di setiap wilayah daerah yang sering disebut juga regionalisasi. Umumnya regionalisasi mengarah pada pendistribusian wewenang pemerintah pusat yang diberikan kepada kantor pusat di daerah dalam bentuk beberapa pelayanan publik, sehingga menyerupai kantor cabang. Urusan pelayanan publik itu ada yang sifatnya sektoral dan ada pula pelayanan yang fungsional. Sedangkan Local administration, adalah jenis desentralisasi yang menjadikan seluruh subordinasi pemerintahan dalam suatu negara adalah sebagai agen pemerintah pusat. Biasanya yang menjadi agen pemerintah pusat tersebut adalah lembaga-lembaga eksekutif. Administrasi lokal tersebut ada yang bersifat mengikat (integrated) dan ada administrasi lokal yang tidak terintegrasi (unintegrated). Dalam pandangan Irawan Soejipto (1976: 33-34), desentralisasi dalam pemahaman administratif diartikan sebagai wewenang pemerintah pusat yang dilaksanakan dengan cara melimpahkannya kepada organ pemerintah yang dibentuk dan ditempatkan di wilayah daerah, dimana limpahan kewenangan tersebut diberikan melalui pejabat-pejabat pemerintah daerah.

Berdasarkan hal itu dapat dikatakan bahwa secara teoritik dekonsentrasi merupakan bagian dari desentralisasi, atau dengan kata lain desentralisasi dalam arti luas mencakup makna dekonsentrasi. Perbedaan dekonsentrasi dan desentralisasi dikemukakan oleh Ateng Syafrudin (2006: v) adalah desentralisasi bermakna bentuk penyerahan sebagian wewenang pemerintah pusat kepada pemerintah daerah atau organ yang lebih bawah, sedangkan dekonsentrasi sebagai bentuk pelimpahan sebagian wewenang antarlembaga pemerintah pusat atau yang di bawahnya. Mengingat demikian, maka kebijakan dekonsentrasi sama pentingnya dengan desentralisasi dalam sistem pemerintahan di Indonesia.

Keuntungan diterapkannya dekonsentrasi menurut Turner (2002) adalah menjadi 1) Accessibility of officials; 2) Mobilization of local resources; 3) Rapid response to local needs; 4) Orientation to the specific local needs; 5) Motivation of field personnel; 6) Inter-office coordination; dan 7) Central agencies. Secara lebih lengkap, Turner menulis sebagai berikut:

a. Accessibility of officials. Officials are available for consultation, advice, and complaint. As local officials can exercise decentralized authority, they make the decisions and do not need to pass them up the line to distant central offices.

b. Mobilization of local resources. It is easier for locally based officials to identify local resources, both human and physical, and then mobilize them in the pursuit of locally determined developmental purposes. Officials should also be familiar with specific local constraints and the dynamics of local politics.

c. Rapid response to local needs. Officials are better placed to respond rapidly to local needs as they are in the territory and fully aware of local conditions.

d. Orientation to the specific local needs. Because officials know the local conditions, they are well placed to make decisions and allocate resources which fit with the specific conditions prevailing in a particular territory. Each sub-national territory may have some unique features which can be taken into account when planning and allocating resources. 
e. Motivation of field personnel. Appointed government officials are more motivated to perform well when they have greater responsibility for programs they manage.

$f$. Inter-office coordination. Coordination between offices dealing with different functions is more easily achieved at the local level where officials are physically close together and are often familiar with each other.

g. Central agencies. The decentralization of service functions relieves central agencies of routine tasks. Responsibility for these has been passed down to the local level. Central agencies can thus focus on improving the quality of policy. Monitoring locallevel performance and providing assistance to sub-national units are key element of this reformulated central government role.

Pemilihan desentralisasi ataupun dekonsentrasi keberhasilannya bukan semata-mata dari sisi konsep, melainkan dipengaruhi dan ditentukan oleh kondisi lingkungan. Werin (Nasution ; 2000 ; 28) menyatakan bahwa "there is no way of organizing, they will say, sametimes addling: no best policy, approach, or technology. As evidence, they can point to the centralized hierarchical organization have no greater probability of success than fragmented or decentralized ones. Kenyataannya permasalahan lebih banyak ditentukan dari realitas di lapangan. Permasalahan tersebut bisa timbul pada level pemerintah pusat maupun pemerintah daerah disebabkan adanya keterbatasan akan sumber daya.

Pembakuan dekonsentrasi dipandang sebagai formulasi yang akan merekatkan kembali berbagai persepsi dan implementasi desentralisasi yang menyalahi penggunaan, sehingga jalinan interkoneksi dan ketergantungan antarpemerintahan menjadi terciptakan, dan mencegah terjadinya ketergantungan mutlak dan represif sebagaimana pengalaman pemerintahan di masa lalu. Interkoneksi tersebut menjadi temali yang mengikat kebersamaan gerak dengan memfungsikan kantor-kantor atau badan-badan dan juga pemerintahan yang berada di struktur menengah untuk menjadi tangan kanan pelimpahan kewenangan pemerintah pusat. Dengan kata lain interkoneksi adalah perwujudan responsibilitas kebijakan pemerintah pusat kepada pemerintah daerah atau semi organisasi-otonom yang kedudukannya tidak dikontrol oleh pemerintah pusat, namun tetap bertanggung jawab kepada pemerintah pusat (Schneider, 2003: 12).

\section{Fungsi Kewenangan Dekonsentrasi}

Kewenangan dalam penyelenggaraan dekonsentrasi mengalami pasang surut dalam perubahan struktur pemerintahan di Indonesia. Sejalan dengan kebutuhan kebangsaan, perubahan struktur pemerintahan melalui peraturan perundang-undangan yang ada telah ada telah mengalami delapan kali perubahan sejak kemerdekaan. Pada dasarnya kebijakan dekonsentrasi mendapat perhatian pada perubahan di tahun 1945 dan 1965. Sedangkan perubahan yang menyeimbangkan antara desentralisasi dan dekonsentrasi mengalami tiga kali, yakni tahun 1957; tahun 1974; dan tahun 2004. Selengkapnya perubahan kebijakan tersebut dapat diperhatikan, sebagai berikut:

a. UU No. 1 Tahun 1945 lebih menitikberatkan pada kebijakan dekonsentrasi.

b. UU No. 22 Tahun 1948 lebih menitik beratkan pada kebijakan desentralisasi.

c. UU No. 1 Tahun 1957 mengabungkan kebijakan desentralisasi dan dekonsentrasi.

d. Perpres No. 6 Tahun 1959 menitikberatkan pada kebijakan dekonsentrasi.

e. UU No. 18 tahun 1965 menitikberatkan pada kebijakan desentralisasi.

f. UU No. 5 Tahun 1974 menggabungkan kebijakan desentralisasi, dekonsentrasi, dan tugas perbantuan.

g. UU No. 22 tahun 1999 menitikberatkan pada kebijakan desentralisasi.

h. UU No. 32 Tahun 2004 penggabungan kebijakan desentralisasi, dekonsentrasi, dan tugas pembantuan.

Tugas dan wewenang penyelenggaraan dekosentrasi pada UU Nomor 5 Tahun 1974 menunjukkan kepala wilayah mendapat pelimpahan wewenang untuk melaksanakan dekonsentrasi dalam hal: 
a. Membina ketentraman dan ketertiban di wilayah sesuai dengan kebijakan ketentraman dan ketertiban yang ditetapkan oeh pemerintah.

b. Melaksanakan segala usaha dan kegiatan di bidang pembinaan idiologi negara dan politik dalam negeri serta pembinaan kesatuan bangsa sesuai dengan kebijaksanaan yang ditetapkan pemerintah.

c. Menyelenggarakan koordinasi atas segala kegiatan dan antara instansi-instansi vertikal. Instansi vertikal dengan dinas-dinas daerah, baik dalam perencanaan, pelaksanaan untuk mencapai dayaguna dan hasilguna yang sebesar-besarnya.

d. Membimbing dan mengawasi penyelenggaraan pemerintahan daerah.

e. Mengusahakan secara terus-menerus segala peraturan perundangan-undangan dan peraturan daerah dijalankan oleh instansi pemerintah pusat dan pemerintah daerah serta pejabat-pejabat yang ditugaskan untuk itu serta mengambil segala tindakan yang dianggap perlu untuk menjamin kelancaran penyelenggaraan pemerintahan.

f. Melaksanakan segala tugas pemerintahan yang dengan atau berdasarkan peraturan perundang-undangan diberikan kepadanya.

g. Melaksanakan segala tugas pemerintahan yang tidak termasuk dalam tugas sesuatu instansi lainnya.

Sedangkan fungsi dan wewenang pejabat dekonsentrasi yang melekat pada jabatan Gubernur berdasarkan PP nomor 39 Tahun 2001 terbagi dalam sepuluh butir, yaitu: (1) Mengaktualisasikan Nilai Pancasila; (2) Mengkoordinasikan manajeman wilayah; (3) Memfasilitasi kerjasama dan mengatasi konflik; (4) Melantik Bupati/Walikota; (5) Memelihara hubungan antardaerah; (6) Memfasilitasi perencanaan dan penegakan perundang-undangan; (7) Menyelenggarakan tugas-tugas lain (urusan pemerintahan); (8) Merencanakan pemindahan kabupaten/kota; (9) Melakukan penega kan represif antardaerah provinsi , kabupaten/kota; dan (10) Memberikan pertimbangan pembentukan dan pemekaran wilayah.

Selanjutnya pada Undang-undang nomor 32/2004 tugas kewenangan desentralisasi untuk pemerintah provinsi menjadi lebih kuat. Tugas dan wewenang Gubernur sebagai wakil pemerintah pusat tersebut diperas menjadi tiga bagian, yaitu pemerintah provinsi sebagai wakil pemerintah berkewajiban melaksanakan pembinaan dan pengawasan kepada pemerintah kabupaten/kota diatur dalam Pasal 38 ayat (1) UU Nomor 32 tahun 2004, yaitu:

a. Pembinaan dan pengawasan penyelenggaraan pemerintahan daerah kabupaten/kota.

b. Koordinasi penyelenggaraan urusan Pemerintah di daerah provinsi dan kabupaten/kota;

c. Koordinasi pembinaan dan pengawasan penyelenggaraan tugas pembantuan di daerah provinsi dan kabupaten/kota.

Dalam PP Nomor 7 Tahun $2008^{\dagger}$ tentang Dekonsentrasi dan Tugas Pembantuan menyatakan bahwa dalam penyelenggaraan urusan pemerintahan yang dilimpahkan oleh Pemerintah, gubernur sebagai wakil Pemerintah melakukan:

a. sinkronisasi dengan penyelenggaraan urusan pemerintahan daerah;

b. penyiapan perangkat daerah yang akan melaksanakan program dan kegiatan dekonsentrasi; dan

c. koordinasi, pengendalian, pembinaan, pengawasan dan pelaporan.

\section{Penyelenggaraan Kewenangan Dekonsentrasi}

Mekanisme pelimpahan urusan pemerintahan melalui dekonsentrasi dilakukan dengan mekanisme penyerahan atas usul pemerintah daerah terhadap bagian urusan-urusan pemerintah yang akan diatur dan diurusnya tersebut. Berbagai usulan itu kemudian

\footnotetext{
PP Nomor 7 Tahun 2008, tentang Dekonsentrasi dan Tugas Pembantuan belum operasional dikarenakan baru ditetapkan pada tanggal 4 Februari 2008, disamping itu berbagai aturan pelaksananya juga belum ditetapkan leh departemen sektoral
} 
dilakuakan verifikasi oleh pihak Pemerintah pusat. Sebelum itu pemerintah pusat juga memberikan penjelasan atas bagian urusan-urusan apa yang saat ini masih menjadi kewenangan Pusat dengan cara menyandarkan pada kriteria eksternalitas; akuntabilitas dan efisiensi yang sepantasnya diserahkan kepada Daerah.

Di dalam UU Nomor 33 tahun 2004 tentang Perimbangan Keuangan antara Pemerintah Pusat dan Pemerintahan Daerah, dinyatakan bahwa dana dekonsentrasi adalah dana yang berasal dari APBN yang dilaksanakan oleh gubernur sebagai wakil Pemerintah yang mencakup semua penerimaan dan pengeluaran dalam rangka pelaksanaan Dekonsentrasi yang di dalamnya tidak termasuk dana yang dialokasikan untuk instansi vertikal pusat di daerah. Besarnya dana disesuaikan dan diselaraskan dengan pembagian kewenangan antara Pemerintah dan Daerah. Dalam hal semua sumber keuangan yang melekat pada setiap urusan pemerintah yang diserahkan kepada daerah menjadi sumber keuangan daerah.

Dalam hal ini pemerintah daerah diberi hak untuk mendapatkan sumber keuangan yang diantaranya dari ketersediaan pendanaan dari Pemerintah sesuai dengan urusan pemerintah yang diserahkan; kewenangan memungut dan mendayagunakan pajak dan retribusi daerah dan hak untuk mendapatkan bagi hasil dari sumber-sumber daya nasional yang berada di daerah dan dana perimbangan lainnya; hak untuk mengelola kekayaan Daerah dan mendapatkan sumber-sumber pendapatan lain yang sah serta sumber-sumber pembiayaan, sebagaimana tercantum pada Pasal 15 UU No 32 Tahun 2004 sebagai berikut:

(1) Hubungan dalam bidang keuangan antara Pemerintah dan pemerintahan daerah sebagaimana dimaksud dalam Pasal 2 ayat (4) dan ayat (5) meliputi:

a. pemberian sumber-sumber keuangan untuk menyelenggarakan urusan pemerintahan yang menjadi kewenangan pemerintahan daerah;

b. pengalokasian dana perimbangan kepada pemerintahan daerah; dan

c. pemberian pinjaman dan/atau hibah kepada pemerintahan daerah.

(2) Hubungan dalam bidang keuangan antarpemerintahan daerah sebagaimana dimaksud dalam Pasal 2 ayat (4) dan ayat (5) meliputi:

a. bagi hasil pajak dan nonpajak antara pemerintahan daerah provinsi dan pemerintahan daerah kabupaten/kota;

b. pendanaan urusan pemerintahan yang menjadi tanggung jawab bersama;

c. pembiayaan bersama atas kerja sama antardaerah; dan

d. pinjaman dan/atau hibah antarpemerintahan daerah.

(3) Hubungan dalam bidang keuangan sebagaimana dimaksud pada ayat (1) dan ayat (2) diatur dalam peraturan perundang-undangan.

Pada UU No 17 Tahun 2003 terdapat penegasan bidang pengelolaan keuangan dimana kekuasaan pengelolaan keuangan negara adalah bagian dari kekuasaan pemerintahan. Kekuasaan pengelolaan keuangan negara dari Presiden sebagian diserahkan kepada Gubernur/Bupati/Walikota selaku kepala pemerintahan daerah untuk mengelola keuangan daerah dan mewakili pemerintah daerah dalam kepemilikan kekayaan daerah yang dipisahkan. Ketentuan tersebut berimplikasi pada pengaturan pengelolaan keuangan daerah, yaitu bahwa Gubernur/Bupati/Walikota bertanggung jawab atas pengelolaan keuangan daerah. Dengan demikian pengaturan pengelolaan dan pertanggungjawaban keuangan daerah melekat dan menjadi satu dengan pengaturan pemerintahan daerah, yaitu dalam undangundang mengenai Pemerintahan Daerah.

Pasal 87 UU No 17 Tahun 2003 menyebutkan: (1) Pendanaan dalam rangka Dekonsentrasi dilaksanakan setelah adanya pelimpahan wewenang Pemerintah melalui kementerian negara/lembaga kepada gubernur sebagai wakil Pemerintah di Daerah; (2) Pelaksanaan pelimpahan wewenang sebagaimana dimaksud pada ayat (1) didanai oleh Pemerintah; (3) Pendanaan oleh Pemerintah sebagaimana dimaksud pada ayat (2) disesuaikan dengan wewenang yang dilimpahkan; (4). Kegiatan Dekonsentrasi di Daerah dilaksanakan oleh SKPD yang ditetapkan oleh gubernur; (5). Gubernur memberitahukan rencana kerja dan 
anggaran kementerian negara/lembaga yang berkaitan dengan kegiatan Dekonsentrasi di Daerah kepada DPRD; (6). Rencana kerja dan anggaran sebagaimana dimaksud pada ayat 6 diberitahukan kepada DPRD pada saat pembahasan RAPBD; dan (7). Pendanaan sebagaimana dimaksud pada ayat (3) dialokasikan untuk kegiatan yang bersifat nonfisik.

Pasal 89 UU Nomor 33/2004 tentang Perimbangan Keuangan antara Pemerintah Pusat dan Daerah dijelaskan mekanisme penyaluran Dana Dekonsentrasi dilakukan melalui Rekening Kas Umum Negara. Pada setiap awal tahun anggaran gubernur sebagai kepala pemerintahan provinsi akan menetapkan Satuan Kerja Perangkat Daerah untuk menjadi pelaksana kegiatan Dekonsentrasi. Apabila terdapat sisa anggaran lebih atas pelaksanaan Dekonsentrasi, maka sisa tersebut merupakan penerimaan kembali APBN. Demikian juga dalam hal terdapat saldo kas atas pelaksanaan Dekonsentrasi, maka saldo tersebut harus disetor ke Rekening Kas Umum Negara. Bilamana pelaksanaan Dekonsentrasi menghasilkan penerimaan, maka penerimaan tersebut juga dipandang sebagai penerimaan APBN dan karenannya harus disetor melalui Rekening Kas Umum Negara sesuai dengan peraturan perundang-undangan yang berlaku.

Berkenaan dengan mekanisme pertanggungjawaban dan juga Pelaporan Dana dekonsentrasi dijelaskan oleh Pasal 90 UU Nomor 33 tahun 2004, yaitu: Penatausahaan keuangan dalam pelaksanaan Dekonsentrasi harus dilakukan secara terpisah dari penatausahaan keuangan dalam bidang pelaksanaan Tugas Pembantuan dan Desentralisasi. SKPD menyelenggarakan penatausahaan uang/barang dalam rangka Dekonsentrasi itu mesti dilakukan secara tertib sesuai dengan peraturan perundang-undangan yang berlaku. SKPDSKPD tersebut senantiasa menyampaikan laporan akan pelaksanaan kegiatan Dekonsentrasi yang diperolehnya kepada gubernur, yang selanjutnya Gubernur menyampaikan laporan pertanggungjawaban secara keseluruhan menganai pelaksanaan kegiatan Dekonsentrasi kepada para menteri negara ataupun pimpinan lembaga yang memberikan pelimpahan wewenang dekonsentrasi. Akhirnya para menteri negara atau pimpinan lembaga tersebut kemudian menyampaikan laporan pertanggungjawaban pelaksanaan kegiatan Dekonsentrasi secara nasional kepada Presiden.

Mengenai status barang yang digunakan dalam pelaksanaan dekonsentrasi diatur melalui Pasal 91 UU Nomor 33 tahun 2004. Dalam ketentuan bahwa semua barang yang diperoleh dari dana dekonsentrasi adalah menjadi barang milik Negara. Barang miliki negara itu dihibahkan kepada Daerah yang wajib untuk dikelola dan diarsipkan. Sedangkan barang milik negara yang tidak dihibahkan kepada Daerah wajib dikelola dan ditatausahakan oleh pihak kementerian negara atau lembaga yang memberikan pelimpahan wewenang.

\section{Kelembagaan Dekonsentrasi, Mekanisme Penyelenggaraan, dan Koordinasi Pelaksanaan Dekonsentrasi di Tingkat Provinsi}

Secara implisit dapat ditemukan bahwa UU Nomor 32 tahun 2004 hanya mengenal satu bentuk kelembagaan dekonsentrasi di Provinsi, yaitu "Gubernur selaku Wakil Pemerintah". Sehubungan dengan hal tersebut, pertanyaan yang muncul adalah: apakah hanya "Gubernur selaku Wakil Pemerintah" saja, kelembagaan yang akan menangani urusanurusan dekonsentrasi di Provinsi?

Untuk menjawab pertanyaan diatas, pertama kali harus dipahami bahwa kelembagaan "Gubernur selaku Wakil Pemerintah" hanya mungkin untuk menjalankan tugas-tugas dekonsentrasi sepanjang menyangkut aspek-aspek pemerintahan umum. Dalam hal ini, Gubernur dibantu oleh unsur Sekretariat dapat disebut sebagai wujud konkrit kelembagaan dekonsentrasi di Provinsi. Namun, untuk kewenangan yang bersifat sektoral, jelas bahwa kelembagaan ini kurang tepat untuk menanganinya.

Dalam Pasal 5 (2) PP nomor 39 Tahun 2001 menegaskan bahwa "penyelenggaraan kewenangan bidang lain yang diterima oleh Gubernur, pelaksanaannya dilakukan oleh suatu Unit Organisasi yang ada dalam Dinas Provinsi”. Selanjutnya dalam Pasal 5 (3) dinyatakan bahwa "dalam hal di Provinsi belum ada Dinas Provinsi yang tepat dan sesuai untuk 
menangani suatu bidang kewenangan yang dilimpahkan ... Gubernur dapat menugaskan Perangkat Daerah lainnya dan atau membentuk unit pelaksana secara khusus". Ketentuan Pasal ini juga mengandung permasalahan yang cukup rumit, khususnya yang berkaitan dengan mekanisme penyerahan dan pelaksanaan kewenangan dekonsentrasi, serta koordinasinya dengan pelaksanaan kewenangan desentralisasi.

Selain itu, tidak dapat dihindarkan pertanyaan tentang "asas fungsionalisasi" dalam arti apakah kewenangan dekonsentrasi dapat dilaksanakan secara fungsional oleh perangkat desentralisasi? Jika hal ini dapat dibenarkan, maka secara tidak langsung UU Nomor 32 tahun 2004 mengakui adanya "perangkapan fungsi" aparat daerah, yakni sebagai perangkat daerah otonom sekaligus sebagai perangkat Pusat di daerah. Dengan kata lain, hal ini merupakan suatu kontroversi tersendiri, apakah perangkapan fungsi tadi sejalan dengan semangat otonomi daerah ataukah tidak?

Walaupun ketentuan PP Nomor 39 Tahun 2001 secara implikatif mengandung banyak perdebatan, namun paling tidak paparan diatas dapat mengkonstruksikan secara umum bahwa kelembagaan / aparat dekonsentrasi di Provinsi secara makro terdiri dari tiga unsur, yaitu: 1) Gubernur dan unsur Sekretariat, 2) Dinas Provinsi atau Perangkat Daerah lainnya dalam hal belum ada Dinas, serta 3) Instansi Vertikal tertentu atau Unit Pelaksana Khusus tertentu yang akan dibentuk untuk mewadahi urusan dekonsentrasi tertentu.

Dengan ketentuan sebagaimana tercantum dalam Pasal 5 PP Nomor 39 Tahun 2001 diatas serta perubahannya yaitu PP Nomor 7 Tahun 2008, maka fakta bahwa perangkat vertikal di Provinsi sudah sangat terbatas akibat dari penghapusan kantor-kantor wilayah yang telah dilakukan, tidak perlu dipermasalahkan. Sebab, Gubernur dapat "menitipkan" kewenangan dekonsentrasinya kepada setiap bentuk kelembagaan atau organisasi yang ada di daerahnya, baik yang berupa Dinas, Sekretariat, Lembaga Teknis maupun UPTD, bahkan tidak menutup kemungkinan membebankan kepada badan-badan usaha daerah. Disini yang terpenting justru adalah, bagaimana pola koordinasi yang harus dilakukan oleh Gubernur dan seluruh instansi yang terlibat dalam penyelenggaraan urusan dekonsentrasi tertentu?

Mengenai mekanisme dan kelembagaan penyelenggaraan kewenangan dekonsentrasi tersebut, Pasal 5 PP Nomor 39 Tahun 2001 menyinggung beberapa lembaga yang harus terlibat didalamnya, yakni Gubernur, Perangkat Daerah, Pejabat Pusat di Daerah, Pemerintah Kabupaten/Kota, DPRD, serta Menteri/Pimpinan LPND. Tugas atau peranan masing-masing lembaga dalam operasionalisasi kewenangan dekonsentrasi dapat di deskripsikan secara umum sebagai berikut :

1. Gubernur selaku Kepala Daerah bertugas untuk mengkoordinasikan perangkat daerah yang dibebani tanggung jawab penyelenggaraan kewenangan dekonsentrasi, membina dan mengawasi pelaksanaannya, serta memberitahukan kepada DPRD Provinsi.

2. Gubernur selaku Wakil Pemerintah bertugas untuk mengkoordinasikan perangkat/ pejabat Pusat di Daerah yang dibebani tanggung jawab penyelenggaraan kewenangan dekonsentrasi, membina dan mengawasi pelaksanaannya, serta mempertanggungjawabkan hasilnya kepada pemerintah (cq. Departemen atau LPND yang memberi pelimpahan). Disamping itu, dalam hal-hal yang menyangkut kepentingan makro regional atau lintas Kabupaten/Kota, Gubernur juga bertugas untuk melakukan koordinasi dengan Bupati/Walikota yang bersangkutan.

3. Perangkat Daerah (yang menerima pelimpahan) bertugas untuk menyusun kerangka kerja, mengimplementasikan kerangka kerja yang telah disusun, melakukan koordinasi dengan instansi yang dipandang perlu, menjalankan rambu-rambu atau pedoman yang disusun oleh pemberi pelimpahan, serta melaporkan hasil kerjanya kepada Gubernur selaku Kepala Daerah.

4. Pejabat Pusat di Daerah (yang menerima pelimpahan) bertugas untuk menyusun kerangka kerja, mengimplementasikan kerangka kerja yang telah disusun, melakukan koordinasi dengan Gubernur dan instansi yang dipandang perlu, menjalankan rambu-rambu atau pedoman yang disusun oleh pemberi pelimpahan, serta melaporkan hasil kerjanya kepada 
Gubernur selaku Wakil Pemerintah. Disamping itu, institusi ini juga wajib membina pegawai di lingkungannya serta memberikan saran dan pertimbangan kepada Menteri/Pimpinan LPND dan Gubernur berkenaan dengan penyelenggaraan kewenangan yang dilimpahkan.

5. DPRD Provinsi bertugas untuk ikut memonitor pelaksanaan kewenangan dekonsentrasi di wilayah kerjanya, sekaligus memberikan umpan balik atas pelaksanaan kewenangan dekonsentrasi tersebut. Tugas pemantauan ini terutama diarahkan kepada hal-hal yang menyangkut kepentingan sebagian terbesar masyarakat di daerah, atau yang menyangkut penggunaan sumber-sumber daya dalam jumlah besar, misalnya anggaran.

6. Menteri/Pimpinan LPND bertugas melakukan pembinaan dan pengawasan atas penyelenggaraan kewenangan yang dilimpahkan kepada Gubernur atau Perangkat Pusat di Daerah, serta menerima pertanggungjawaban atas pelaksanaan kewenangan tersebut.

Dengan rincian tugas masing-masing lembaga diatas, maka pola atau mekanisme koordinasi dalam penyelenggaraan kewenangan dekonsentrasi dapat digambarkan sebagai berikut.

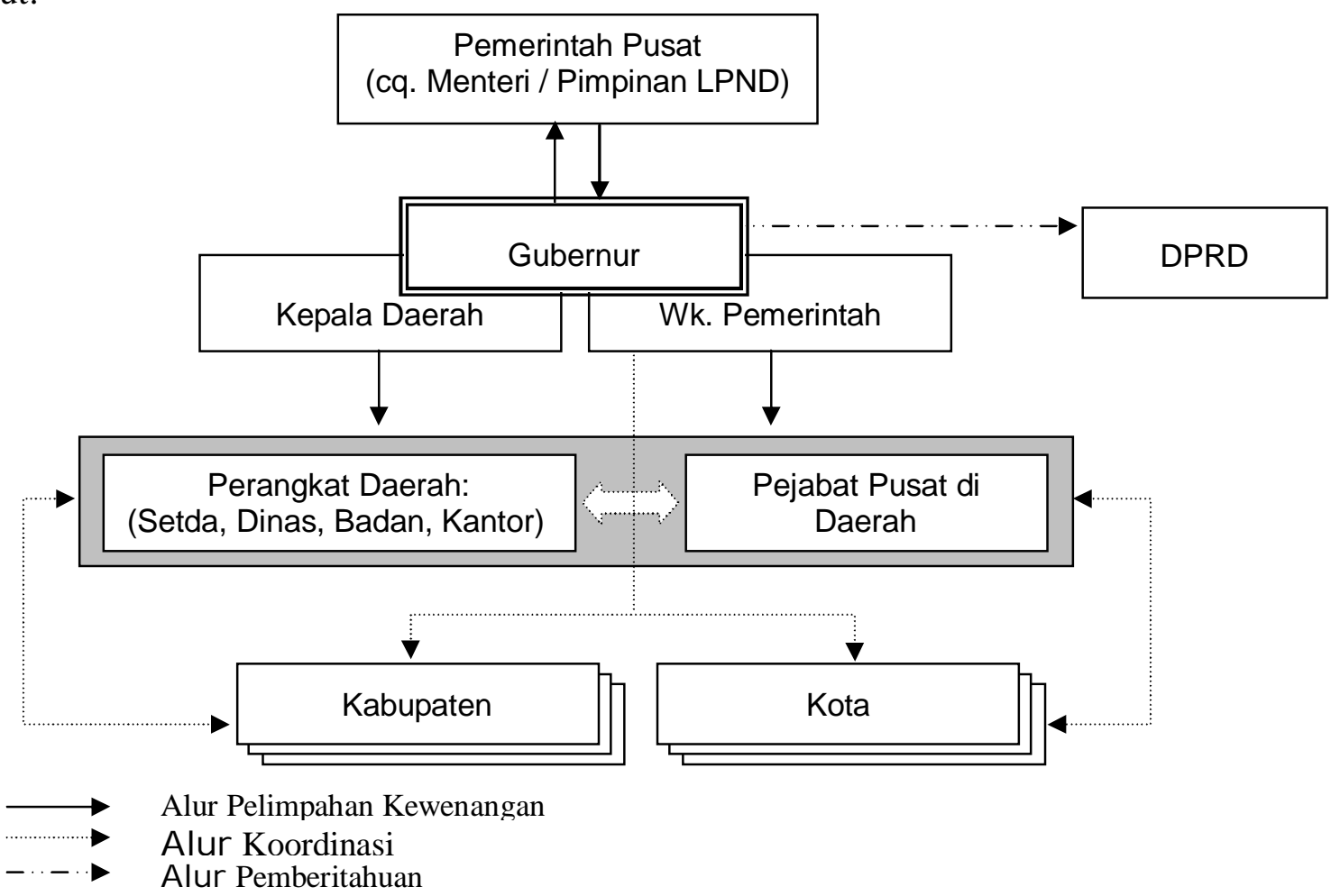

Gambar 1

Pola Koordinasi Dalam Penyelenggaraan Kewenangan Dekonsentrasi di Provinsi

Bagan diatas mengasumsikan bahwa kewenangan dekonsentrasi dan desentralisasi dapat dilaksanakan secara bersama-sama dengan penggunaan SDM dan mekanisme yang sama pula. Padahal, secara substansial keduanya memiliki perbedaan yang cukup mendasar. Pada kewenangan desentralisasi, landasan hukum yang memayunginya adalah Perda tentang Pembentukan Perangkat Daerah dan/atau SOTK yang antara lain mengatur tugas pokok dan fungsi (desentralisasi) Perangkat Daerah tertentu. Tugas pokok dan fungsi yang tertera dalam Perda ini sifatnya relatif permanen. Artinya, tugas pokok dan fungsi ini akan tetap ada dan dilaksanakan sepanjang Perangkat Daerah yang bersangkutan juga masih ada. Sementara tugas-tugas yang berasal dari pelimpahan wewenang, sifatnya relatif temporer. Artinya, tugas-tugas tersebut dapat diberikan sewaktu-waktu dan ditarik sewaktu-waktu oleh pihak yang memiliki kewenangan.

Dengan sifat tugas yang berbeda seperti ini, maka pola kerjanya pun menjadi berbeda pula. Penyelenggaraan kewenangan desentralisasi lebih bersifat siklis, repetitif 
dan rutin, sementara penyelenggaraan kewenangan dekonsentrasi lebih bersifat linier, insidental dan kontingensial. Perbedaan pola kerja ini dapat digambarkan dalam Gambar berikut.

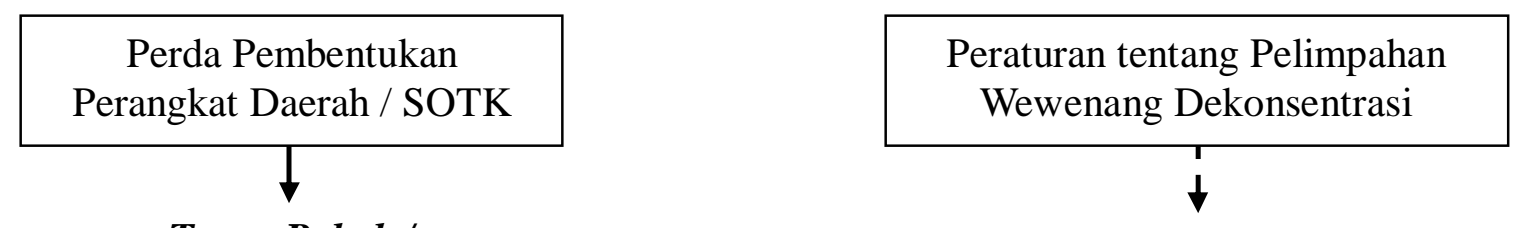

\section{Tugas Pokok / \\ Desentralisasi}

\section{Dekonsentrasi /}

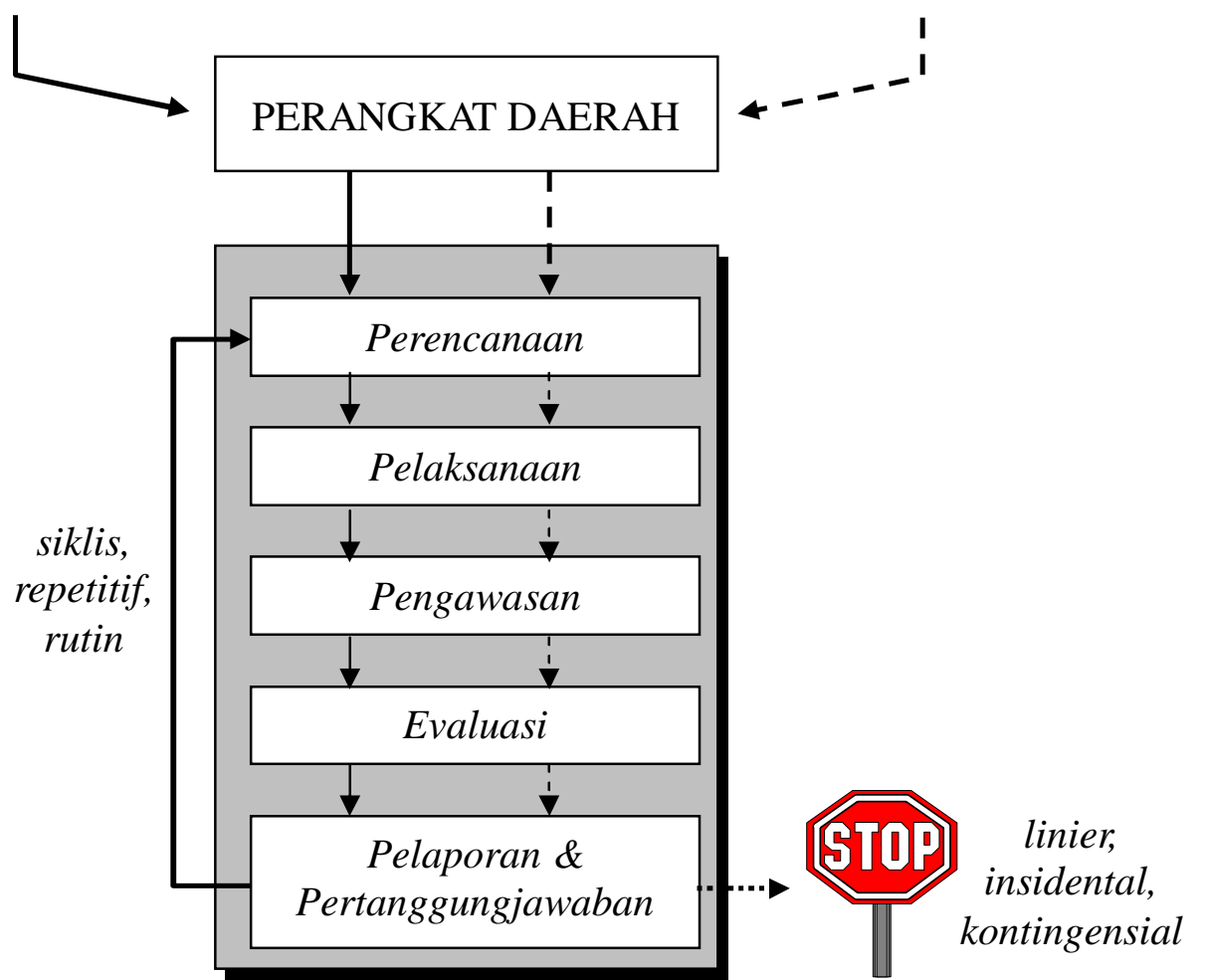

Gambar 2

Perbandingan Pola Kerja Kewenangan Desentralisasi dan Kewenangan Dekonsentrasi

\section{Indikasi Umum Penyelenggaraan Kewenangan Dekonsentrasi di Provinsi}

Hasil penelitian di lapangan menunjukkan bahwa pada umumnya responden memandang perlu adanya koordinasi kewilayahan di dan/atau oleh Provinsi. Dalam hal ini, jenis-jenis koordinasi yang dibutuhkan meliputi koordinasi terhadap fungsi-fungsi perencanaan, pelaksanaan, pembinaan, pengawasan dan pengendalian, serta koordinasi dalam bidang-bidang kelembagaan dan sektoral. Bahkan, fungsi koordinasi ini semakin krusial dengan sistem otonomi luas untuk Kabupaten/Kota. Dalam hubungan ini, koordinasi diharapkan dapat berperan sebagai "tali pengikat" antara Provinsi dengan Kabupaten/Kota, serta antar Kabupaten/Kota di wilayah Provinsi yang bersangkutan. Dengan demikian, koordinasi diharapkan tidak hanya mampu untuk menciptakan efektivitas dan kesinambungan pembangunan sektoral dan regional, namun juga mampu menjamin keutuhan wilayah dalam kerangka Negara Kesatuan RI.

Meskipun demikian, terdapat beberapa hal yang disorot oleh responden sebagai kritik terhadap PP Nomor 39 Tahun 2001. Kritik tersebut berkaitan dengan aspek-aspek sebagai berikut :

1. Secara umum pengertian koordinasi wilayah, perencanaan, pelaksanaan, sektoral, kelembagaan, pembinaan, pengawasan dan pengendalian sebagaimana tertuang dalam 
Pasal 3 UU No. 39 Tahun 2001 dan penjelasannya belum operasional. Hal ini dapat mengakibatkan disorientasi daerah dalam merealisasikan fungsi koordinasi tersebut. Oleh karena itu, aspek-aspek detail tentang koordinasi tadi perlu dielaborasi lebih dalam, misalnya mengenai proses / mekanisme, lembaga terkait, tugas dan wewenang dan tanggung jawab setiap lembaga, alat koordinasi, dan sebagainya. Dalam hal ini, bentuk peraturan perundangan yang diusulkan berupa Peraturan Pemerintah (PP).

2. Khususnya yang menyangkut pengertian koordinasi pembinaan dan koordinasi pengawasan seperti tertuang dalam Pasal 3 butir (b) sedikit menimbulkan kebingungan atau kerancuan. Selama ini koordinasi dipahami sebagai fungsi manajemen yang lebih bersifat horisontal dan diagonal, bukan sesuatu yang subordinatif. Sementara dalam fungsi-fungsi pembinaan, bimbingan, supervisi dan pengawasan tersirat adanya hierarki, jenjang dan subordinasi. Untuk itu, sesuai dengan sistem otonomi yang tidak mengenal tingkatan dalam daerah otonom, maka perlu dipertegas bahwa koordinasi pembinaan dan koordinasi pengawasan tidak dimaknakan sebagai suatu bentuk "campur tangan" Gubernur atau Wakil Pemerintah Pusat di Daerah terhadap urusan-urusan rumah tangga daerah otonom.

3. Dalam praktek penyelenggaraan pemerintahan di daerah selama ini dikenal adanya forum MUSPIDA sebagai koordinator kebijakan pimpinan daerah. Dengan berlakunya UU Pemerintahan Daerah yang baru (UU No 22/1999 dan UU No. 32/2004) yang lebih menonjolkan paradigma demokratisasi, partisipasi, pemberdayaan dan pemerataan, maka struktur dan figur forum MUSPIDA perlu dirumuskan ulang. Dalam hal ini, unsur atau komponen masyarakat (baik secara langsung maupun melalui sistem perwakilan) perlu lebih diakomodasikan dalam forum-forum konsultasi lintas stakeholder.

4. Meskipun status otonomi Kabupaten/Kota menurut UU Nomor 32 tahun 2004 bersifat bulat, utuh dan luas, namun mereka masih memandang keberadaan PP Nomor 6 Tahun 1988 sebagai dasar koordinasi yang masih relevan untuk diimplementasikan. Hal ini mengindikasikan bahwa peran Gubernur selaku Wakil Pemerintah masih diakui dan dihormati oleh Kabupaten/Kota. Namun hal ini tidak berarti bahwa PP Nomor 6 Tahun 1988 tersebut tidak memerlukan peninjauan. Revisi terhadap PP ini penting untuk dilakukan, terutama untuk memberikan porsi yang lebih besar kepada masyarakat dan pemerintah Kabupaten/Kota dalam penyelenggaraan koordinasi pembangunan dan pemerintahan, sekaligus melimitasi peran aparat vertikal atau wakil pemerintah. Perubahan terhadap PP Nomor 6 Tahun 1988 ini juga dipandang mendesak mengingat PP Nomor 39 Tahun 2001 tidak mengatur secara tegas dan jelas mengenai sistem koordinasi yang harus dijalankan. Salah satu klausul yang perlu mendapat perhatian khusus adalah yang menyangkut tindakan administratif bagi instansi vertikal atau dinas daerah yang lalai atau tidak mengindahkan pelaksanaan koordinasi. Responden pada umumnya lebih menginginkan agar kepada dinas/badan/lembaga yang ada diberikan tanggungjawab dan kepercayaan yang lebih besar, dari pada sekedar mengancam dengan sanksi administratif.

5. Mengingat bahwa sistem otonomi saat ini sangat berbeda dengan sistem yang dianut UU Nomor 5 tahun 1974, maka seluruh Keputusan Gubernur dan Bupati/Walikota yang menyangkut pelaksanaan koordinasi seperti (jika ada), perlu disesuaikan kembali. Bahkan PP Nomor 39 Tahun 2001 sendiri harus masuk sebagai agenda perubahan (revisi) yang mendesak.

\section{Penyelenggaraan Kewenangan Dekonsentrasi di Daerah}

Dalam prakteknya, penyelenggaraan kewenangan dekonsentrasi didaerah, sejauh ini baru sebatas hanya pelimpahan kewenangan untuk pengelolaan anggaran yang dikucurkan melalui departemen-departemen sektoral yaitu dengan memberikan kewenangan kepada Gubernur untuk mengusulkan perangkat pengelola keuangan (Kuasa Pengguna Anggaran, Bendahara Pengeluaran, Bendahara Penerimaan, Pejabat Pembuat Komitmen serta Pejabat Penguji dan Perintah Pembayaran). Dalam prakteknya, mekanisme usulan ini hanya terjadi 
secara administratif persuratan saja, sehingga tidak ada tindak lanjut lebih jauh terhadap peran gubernur sebagai subjek langsung yang diberi amanat oleh Undang Undang sebagai pelaksana dari kewenangan dekonsentrasi.

Dimana sejauh ini dalam proses pengelolaan kegiatan yang pendanaanya bersumber dari anggaran dekonsentrasi belum terbangunnya mekanisme kerja yang secara langsung melibatkan Gubernur. Kalaupun ada keterlibatan Bappeda selaku perangkat kerja pemerintah provinsi hanya sebatas pada laporan besaran anggaran yang di kucurkan oleh masing-masing departemen, namun dibeberapa daerah di Kalimantan, pelibatan Bappeda dalam proses perencanaan dan pelaporan pelaksanaan kewenangan dekonsentrasi sangat minim. Sehingga tidak sedikit, para gubernur tidak megetahui secara persis jenis kewenangan dan kegiatan apa saja yang dibiayai oleh departemen tertentu didaerahnya, bagaimana pengelolaanya dan bagaimana capaian kinerja dari masing-masing program tersebut.

Praktek seperti ini terjadi di banyak daerah, seperti yang terjadi di Jawa Barat. Dimana dalam proses penganggaran, pelaksanaan program dan pelaporan kegiatan selama ini langsung dikoordinasikan oleh departemen terkait langsung dengan dinas-dinas di daerah. Dalam satu kesempatan Gubenur Jawa Barat, Dany Setyawan menyatakan bahwa dana dekonsentrasi selama ini langsung ditangani oleh departemen sektoral di pusat yang penyalurannya langsung disampaikan kepada dinas. Mekanisme seperti itu, mencerminkan bahwa departemen sektoral masih menganggap dan mengobsesikan dinas-dinas yang ada di provinsi seperti kanwil (kantor wilayah) dulu. (PR, 13 April 2005).

Pernyataan gubernur Jawa Barat tersebut, memang tidak berlebihan jika melihat bagaimana praktek penyelenggaraan dekonsentrasi yang selama ini terjadi. Seiring dengan diberlakukannya otonomi daerah, keberadaan satuan kerja pemerintah pusat di daerah yang dulunya direpresentrasikan oleh kantor-kantor wilayah telah dihapuskan. Dimana dulunya pembiayaan semua program dan kegiatan terhadap kantor-kantor wilayah tersebut sepenuhnya terintegrasi kedalam pembiayaan masing-masing departemen terkait.

Selanjutnya, di era otonomi daerah sekarang ini penyelenggaraan kewenangan pemerintah baik kewenangan absolute (politik luar negeri, agama, moneter, yustisi, pertahanan dan keamanan) maupun kewenangan pemerintah lainnya di daerah, dapat diselenggarakan sendiri oleh pemerintah melalui instansi-instasinya di daerah (instansi vertikal) atau melimpahkan sebagian urusan pemerintahan tersebut kepada Gubernur selaku wakil Pemerintah (dekonsentrasi), atau dapat menugaskan sebagian urusan kepada pemerintahan daerah dan/atau pemerintahan desa berdasarkan asas tugas pembantuan.

Sudah hampir empat tahun implementasi undang-undang pemerintah daerah dilaksanakan, namun sejauh ini yang sudah sepenuhnya dilaksanakan dan diatur dengan peraturan perundang-undangan yang lebih teknis adalah desentralisasi, sedangkan asas dekonsentrasi dan tugas perbantuan sejauh hanya dari aspek pembiayaannya yang sudah dilakukan, namun ironisnya aturan pelaksanaan yang lebih operasional yang bersifat substansial terhadap pelaksanaan asas dekonsentrasi dan tugas perbantuan itu sendiri belum ada.

Implikasi lebih jauh dari belum adanya aturan yang lebih operasional yang mengatur mengenai jenis kewenangan yang dilimpahkan ke gubenur, mekanisme pelimpahannya, kejelasan mekanisme pembiayaan dan ketegasan pertanggungjawaban sebagaimana peraturan yang telah ditetapkan, menyebabkan pertanggungjawaban pengelolaan anggaran dekonsentrasi di daerah sejauh ini belum berjalan dengan baik. Kondisi ini dibuktikkan dengan laporan audit BPK atas Laporan Keuangan Pemerintah Pusat (LKPP) 2004 memastikan, seluruh departemen yang mengucurkan dana dekonsentrasi tidak dilaporkan dalam LKPP 2004. Pada periode 2001-2003, lebih buruk lagi karena pemerintah sama sekali tidak menyusun LKPP. Pada 2005, pemerintah pusat mengucurkan dana dekonsentrasi Rp 4 triliun dan pertanggungjawabannya mengalami kemajuan karena sebagian dicantumkan dalam LKPP 2005. Namun, BPK masih menemukan dana dekonsentrasi sebesar Rp 2,08 triliun belum dicantumkan dalam LKPP 2005. 
Kondisi tersebut juga dikaitkan belum dengan adanya kegiatan pengawasan dan pembinaan yang berkala dan terencana dengan baik bagi SDM di daerah, baik oleh departemen keuangan maupun oleh departemen terkait yang menyalurkan anggaran.

\section{Praktek Penyelenggaraan Kewenangan Dekonsentrasi di daerah dan Permasalahan di wilayah Kalimantan}

Secara umum penyelenggaraan kewenangan dekonsentrasi oleh pemerintah daerah selama ini baru sebatas kepada kewenangan mengelola anggaran yaitu pelimpahan Kuasa Pengguna Angagran (KPA) dari Menteri kepada gubernur, Kuasa Pengguna Anggaran itu masih dilimpahkan lagi kepada kepala-kepala dinas. Dimana sejumlah dana yang dikucurkan tersebut tidak didahului oleh pelimpahan kewenangan kepada gubernur selaku wakil pemerintah pusat di daerah, sehingga dengan sendirinya sejumlah anggaran yang dikucurkan kepada daerah tersebut tidak jelas dalam rangka menjalankan kewenangan yang mana, sehingga tanpa didahului oleh pelimpahan kewenangannya terlebih dahulu dari pemerintah (departemen terkait).

Sehingga, dalam penyelenggaraanya di lapangan lebih dititikberatkan kepada aspek pengelolaan anggaran, bukan kepada bagaimana kinerja masing-masing jenis kewenangan yang termasuk dalam kategori kewenangan yang didekonsentrasikan. Kondisi ini kemudian menyebabkan penyelenggaraan kewenangan dekonsentrasi ini masih dihadapkan pada berbagai permasalahan di daerah.

Berbagai permasalahan yang dirasakan menjadi permasalahan dalam penyelenggaraan kewenangan dekonsentrasi di daerah, diantaranya yaitu:

\section{Mekanisme Perencaaan}

Persoalan yang dirasakan terhadap menakanisme pengangagran tersebut secara langsung dikontribusikan oleh sisten perencanan yang juga kurang jelas mekanismenya, baik acuan kerja maupun pola koordinasi perencaan dari departemen dengan dinas-dinas.

Proses perencanaan yang telah disusun oleh daerah (dinas-dinas) namun ketika sudah diusulkan departemen/lembaga negara di pusat terjadi perubahan-perubahan yang tidak sesuai dengan apa yang telah direncanakan. Hal ini dikeluhkan oleh beberapa dinas di Provinsi Kalimantan Tengah. Dimana terjadi ketidaksinkronan pada tahap rencana antara rancangan/usulan kegiatan (jenis, sasaran dan ruang lingkup) yang berkonsekuensi terhadap besaran nominal, yang diusulkan daerah dengan DIPA yang ditetapkan oleh departemen. Sehingga dalam operasionalisasi program-program yang telah terlebih dahulu direncanakan berdasarkan kebutuhan dan kondisi daerah kemudian banyak yang tidak dapat secara optimal dilaksanakan. Disisi lain juga membawa dampak psikologis, yaitu melemahkan motivasi perangkat kerja didaerah karena perencanaan yang telah disusun ternyata tidak dijadikan sebagai acuan dalam penetapan program-program tersebut. Oleh karena itu disarankan setiap departemen membuat master plan departemen yang jelas yang dapat dijadikan acuan dalam penyusunan rencana yang terpadu dan sinkron, mulai tingkat nasional hingga desa (sesuai dengan kewenangannya masingmasing) untuk setiap sektor pembangunan yang jelas dan dapat dijadikan acuan oleh dinas-dinas didaerah dalam menyusun perencanaan kegiatan (logical frame work).

Kondisi seperti disebutkan diatas, terjadi hampir disemua dinas dan Provinsi diwilayah Kalimantan. Hal ini lebih menguatkan pendapat sebelumnya, bahwa masih banyak kelemahan yang harus di perbaiki dari penyelenggaraan kewenangan dekonsentrasi ini baik di level daerah maupun pusat. Sistem perencanaan program yang idealnya dilakukan dengan pendekatan bottom up harus juga dilakukan secara konsisten dalam penyelenggaraan kewenangan dekonsentrasi ini.

Sistem perencanaan yang tidak terintegrasi antara perencanaan yang dilakukan oleh depertemen dengan perencanaan yang dilakukan oleh daerah juga berimplikasi kepada tingkat optimalisasi pencapain sasaran dari penyelenggaraan kewenangan dekonsentrasi tersebut di daerah. 


\section{Mekanisme Koodinasi dan Monitoring di Daerah}

Belum adanya mekanisme koordinasi dan pelibatan gubernur (cq. perangkat kerjanya) di daerah diluar dinas terkait di daerah, juga menjadi salah satu permasalahan yang juga dikeluhkan oleh pemerintah provinsi di Kalimantan. Sehingga dibutuhkan suatu mekanisme yang dapat mengintegrasikan proses perencanaan dan pengelolaan program yang lebih efektif di daerah. Sehingga, peran gubernur sebagai pelaku utama dari asas dekonsentrasi itu sendiri dapat dioptimalkan.

Seperti yang terjadi di Provinsi Kalimantan Timur dan Kalimantan Selatan, dimana pelibatan Bappeda selaku perangkat kerja daerah yang selama ini melakukan fungsi koordinasi, perencaan, monitoring dan pelaporan dalam proses pengelolaan dana dekonsentrasi oleh masing-masing dinas sangat lemah. Dimana Bappeda hanya mengetahui besaran anggaran Dekonsentrasi pada waktu perencaannya saja, namun dalam proses selanjutnya sering sekali Bappeda tidak lagi dilibatkan (mendapat laporan) seperti apakah adanya perubahan anggaran dari apa yang telah direncanakan. Sehingga, dalam proses penggalian data dilapangan untuk kegiatan penelitian ini, sering sekali ditemukan perbedaan data yang dimiliki oleh Bappeda dengan data yang ada di dinasdinas.

Kelemahan fungsi monitoring dan koordinasi dalam pengelolaan anggaran dekonsentrasi oleh departemen/instansi pusat terkait juga dikeluhkan oleh dinas-dinas di Kalimantan Tengah, dimana selama ini dinas-dinas tersebut telah melakukan pelaporan terhadap pengelolaan kegiatan di instansinya, namun tidak memperoleh respon secara formal, baik tertulis maupun tidak tertulis dari departemen. Tidak adanya respon ini diartikan oleh daerah bahwa daerah merasa sudah melaksanakan kewajibannya terlepas ada atau tidak-nya kekeliruan dalam administrasi maupun substansi kegiatan yang dilaporkan.

Melihat praktek koordinasi yang terjadi seperti tersebut diatas, maka sangat wajar jika faktor akuntabilitas pengelolaan dana dekonsentrasi selama ini menjadi salah satu perosalan utama. Hal tersebut diperparah dengan kondisi lemahnya fungsi koordinasi dan pengawasan di daerah. Karena jika diperhatikan dari prakteknya selama ini, sepertinya fungsi tersebut terputus ditingkat daerah. Dimana selama ini, dinas-dinas yang bersangkutan langsung berhubungan dengan departemen/instansi pusat yang terkait. Dengan berbagai faktor yang menjadi penghambat, garis koordinasi tersebut menjadi sangat lemah, bahkan dapat dikatakan tidak efektif. Dimana dinas-dinas yang merupakan Satuan Kerja Perangkat Daerah (SKPD) seharusnya dikoordinasikan oleh perangkat kerja daerah dilevel Provinsi juga, dalam hal ini Bappeda yang juga merupakan perangkat kerja Gubernur di daerah, yang selama ini melakukan fungsi koordinasi terutama dalam proses perencanaan, monitoring dan pelaporan terhadap pengelolaan anggaran daerah (APBD) oleh dinas-dinas di daerah.

Tidak adanya fungsi koordinasi dan monitoring yang dilakukan oleh perangkat kerja gubernur yang memang mlakukan fungsi tersebut (Bappeda) dalam pengelolaan dana dekonsenrtasi bisa menjadi salah satu penyebab terbukanya peluang terjadinya tumpang tindih pembiayaan terhadap program-program tertentu yang juga telah dibiayai APBD.

\section{Keterbatasan SDM Pengelola Kegiatan (Keuangan dan Pengelola BMN)}

Perbedaan standar pengelolaan kegiatan antara kegiatan yang dibiayain dengan anggaran yang bersumbe dari APBD dengan kegiatan yang dibiayai oleh APBN secara menyebabkan banyak sumber daya aparatur pengelola kegiatan dekonsenrtasi di daerah tidak memiliki kemampuan untuk melakukan proses pengelolaan kegiatan dengan menggunakan beberapa aplikasi, seperti Sistem Akutansi Instansi (SAI), Sistem Akuntansi Barang Milik Negara (SABMN), aplikasi Surat Perintah Membayar (SPM) dan beberapa standar lainnya. Karena keterbatasn tersebut, menyebabkan banyak satuan kerja 
yang terlambat menetapkan perangkat pengelola anggaran, yang kemudian juga beriimplikasi kepada terlambatnya penyerapan anggaran.

Keterbatasan kemampuan SDM terserbut telah berimplikasi sangat besar terhadap akuntabilitas pengelolaan dana dekonsenrtasi didaerah. Jika ditelusuri lebih jauh, memang kegiatan bimbingan dan pelatihan bagi aparatur pengelola kegiatan terhadap beberapa standar pengelolaan anggaran dengan menggunakan standar aplikasi pengelolaan APBN belum optimal dilakukan oleh departemen (instansi penyedia anggaran).

Permasalahan buruknya pelaporan dan tidak adanya pengadministrasian terhadap barang-barang yang menjadi aset negara (SHBMN) akibat pembiayaan oleh dana dekonsenrtasi adalah permasalahan-permalahan yang juga masih terjadi di daerah, termasuk di Kalimantan. Sebagai contoh adalah, berdasarkan hasil pemeriksanaan BPK terhadap pengelolaan dana dekonsentrasi di Departemen Sososial pada Tahun 2006 menunjukkan bahwa Provinsi Kalimantan Selatan dan Kalimantan Barat sama sekali belum menyerahkan laporan pengelolaan kegiatan ke departemen yang bersangkutan. Permsalahan yang perlu diperhatikan adalah terhadap pembiayaan pemeliharaan barang milik negara (BMN) tersebut, jika status kepemilikan masih menjadi hak Pemerintah dalam artian belum dihibahkan kepada pemerintah provinsi, maka pembiayaan terhadap pemeliharaan BMN tersebut juga semestinya dialokasikan oleh Pemerintah bukan hanya sekedar pengadministrasiannya saja.

\section{Rekomendasi Penyelenggaraan Koordinasi Fungsi Dekonsentrasi di Provinsi}

Paparan diatas telah menggambarkan beberapa aspek pemerintahan wilayah, khususnya yang terkait langsung dengan koordinasi pelaksanaan kewenangan dekonsentrasi di Provinsi. Dari fenomena empirik yang diperoleh selama proses penelitian serta dari analisis akademis maupun kebijakan dapat ditemukan adanya beberapa permasalahan, kejanggalan, kerancuan ataupun disorientasi dalam penyelenggaraan urusan-urusan pemerintah Pusat di Daerah. Oleh karena itu, untuk mengoptimalkan tugas-tugas pelimpahan kewenangan dari Pusat kepada Daerah sekaligus untuk menunjang tugas-tugas desentralisasi, perlu diupayakan adanya integrasi fungsi, integrasi institusi dan integrasi program dalam penyelenggaraan koordinasi kewilayahan di Provinsi. Secara lebih konkrit, makna integrasi fungsi, institusi dan program ini dapat dijelaskan sebagai berikut.

\section{- Integrasi Fungsional}

Dalam ilmu manajemen terdapat fungsi-fungsi yang melekat dalam suatu organisasi baik publik maupun privat. Fungsi-fungsi manajemen tersebut berjumlah banyak sekali, namun dalam skala makronya terdapat 4 (empat) fungsi pokok yaitu perencanaan (planning), pengorganisasian dan pelaksanaan (organizing and actuating), serta pengawasan (controlling). Perencanaan biasanya merupakan fungsi pertama yang harus ditempuh sebagai suatu pedoman atau arah kemana suatu organisasi harus menuju. Untuk dapat menjamin adanya output atau unjuk kerja yang optimal, perencanaan harus memperhatikan standar atau tolok ukur yang harus dinilai pada tahap pengawasan (performance appraisal). Selanjutnya, hasil kerja dan hasil pengawasan perlu diolah dan dianalisis sebagai umpan balik (feedback dan feed-forward) dalam menyusun perencanaan berikutnya.

Dalam kaitan dengan koordinasi, seluruh fungsi manajemen diatas selalu membutuhkan adanya koordinasi antar instansi terkait. Dengan kata lain, koordinasi selalu dibutuhkan sejak penyusunan perencanaan hingga pengawasan. Itulah sebabnya kemudian dikenal adanya istilah koordinasi perencanaan, koordinasi pelaksanaan, serta koordinasi pengawasan sebagaimana diatur dalam Pasal 3 PP Nomor 39 Tahun 2001. Adapun keterkaitan antara koordinasi dengan berbagai fungsi manajemen dapat disederhanakan dalam bentuk mo del dibawah ini.

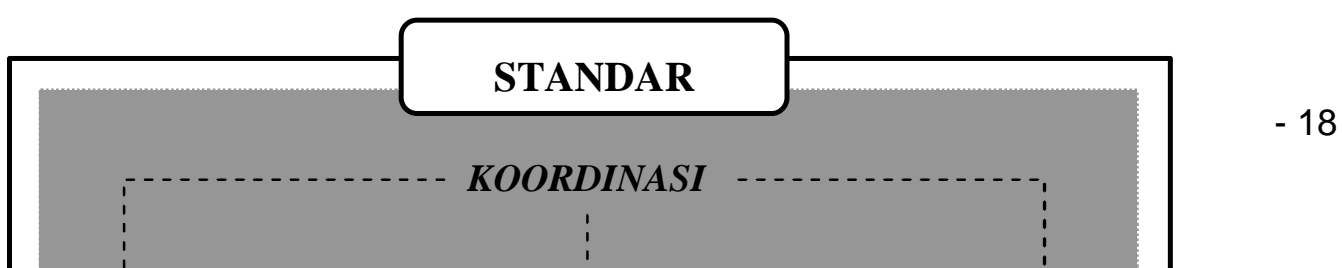




\section{Gambar 3.3}

Integrasi Fungsi-Fungsi Manajemen Dalam Penyelenggaraan Kewenangan Dekonsentrasi di Provinsi

\section{- Integrasi Institusional / Kelembagaan}

Disamping integrasi fungsi, integrasi institusi juga merupakan faktor yang sangat menentukan keberhasilan pelaksanaan pelimpahan kewenangan Pusat di Provinsi. Dalam hubungan ini, kelembagaan yang saling terkait dengan fungsi-fungsi dekonsentrasi meliputi kelembagaan di tingkat Pusat, tingkat Provinsi, serta di Kabupaten/Kota. Mekanisme koordinasinya dapat dijelaskan sebagai berikut. Departemen/LPND mendelegasikan sebagian kewenangannya kepada Gubernur selaku Wakil Pemerintah. Namun, walaupun kewenangan telah dilimpahkan, Menteri / Pimpinan tetap berkewajiban untuk melakukan bimbingan teknis atau fungsional terhadap perangkatnya di daerah (jika ada). Selanjutnya, Gubernur menentukan perangkat daerah mana yang akan diberi tanggung jawab untuk menyelenggarakan kewenangan yang telah dilimpahkan tersebut, apakah kepada Sekretariat, Dinas, Lemtekda, UPTD, atau Perangkat Pusat di Daerah. Dalam hal ini, Gubernur sekaligus melakukan koordinasi dengan instansi di Provinsi serta dengan pemerintah Kabupaten/Kota yang terkait. Pada saat yang bersamaan, perangkat daerah dapat berkoordinasi pula dengan Kabupaten/Kota maupun dengan perangkat pusat di daerah. Pada akhir program, Gubernur wajib mempertanggungjawabkan hasil penyelenggaraan kewenangan dekonsentrasi kepada Menteri/Pimpinan LPND serta memberitahukan kepada DPRD Provinsi.

Dalam bentuk model, integrasi institusi/kelembagaan dalam penyelenggaraan kewenangan dekonsentrasi di Provinsi dapat digambarkan sebagai berikut.

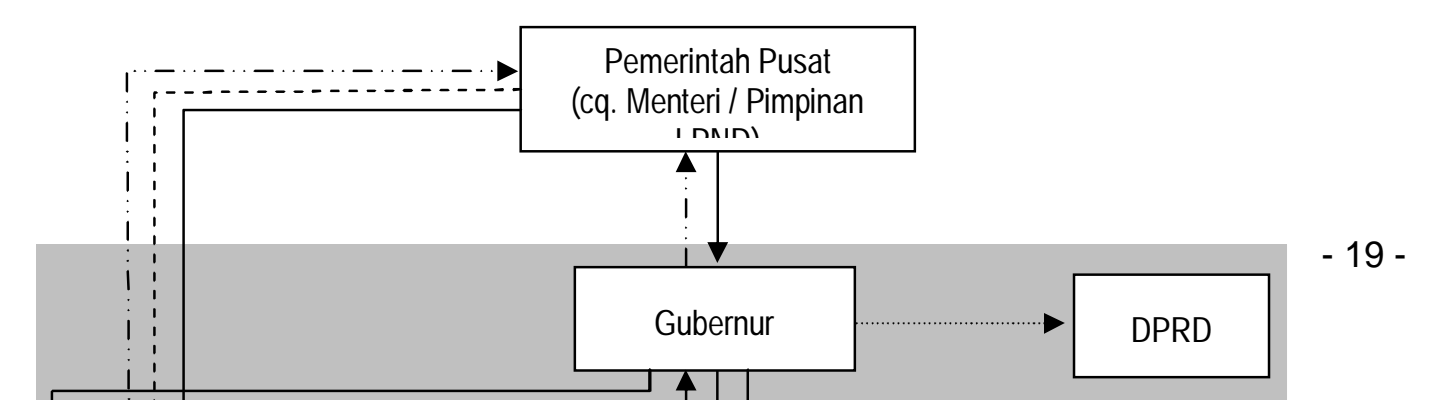




\begin{abstract}
Gambar 3.4
Integrasi Institusi / Kelembagaan Dalam Penyelenggaraan Kewenangan Dekonsentrasi di Provinsi
\end{abstract}

\title{
- Integrasi Program
}

Sebagaimana telah dipahami bersama, program-program pembangunan dan pemerintahan di daerah secara dimensional terdiri dari program sektoral dan program regional. Program sektoral merupakan program-program pemerintah pusat (cq. Departemen / LPND) berdasarkan sektor-sektor tertentu. Sedangkan program regional merupakan pelaksanaan urusan-urusan rumah tangga daerah otonom. Selama ini terdapat kesan bahwa pelaksanaan program sektoral dan regional berjalan sendiri-sendiri berdasarkan visi dan tujuan masing-masing. Namun dengan telah efektifnya implementasi UU Nomor 22 Tahun 1999 - yang bahkan telah direvisi melalui UU Nomor 32 Tahun 2004 - serta pemberlakuan PP Nomor 39 Tahun 2001, maka kedua program tersebut perlu diintegrasikan.

Proses pengintegrasian program-program pembangunan ini dimulai dengan pengintegrasian fungsi perencanaan. Artinya, aparat daerah dan aparat pusat yang memiliki kepentingan terhadap suatu daerah tertentu bertemu bersama-sama pada saat penyusunan rencana program. Dalam tahap perencanaan ini, baik aparat daerah maupun aparat pusat di daerah menetapkan elemen dasar perencanaan yaitu visi, misi, tujuan, maksud, sasaran, dan strategi. Seluruh elemen ini akan direalisasikan dalam bentuk program baik secara sektoral maupun regional. Program yang telah dirumuskan kemudian dilaksanakan oleh aparat masing-masing namun tetap dengan memperhatikan perlunya koordinasi. Fungsi pengawasan terhadap masing-masing dimensi pembangunan juga dilakukan oleh aparat yang bersangkutan. Namun pada saat-saat akhir program, sebaiknya aparat daerah diintegrasikan kembali dengan aparat pusat di daerah untuk melakukan evaluasi. Pada tahap evaluasi ini, beberapa penilaian / pengukuran kinerja yang harus diterapkan antara lain adalah penilaian efektivitas (hasil apa yang dicapai), efisiensi (penggunaan sumber daya untuk mencapai hasil), kecukupan (kemampuan menyelesaikan masalah), perataan (kemampuan mendistribusikan hasil secara adil), responsivitas (kemampuan memuaskan kebutuhan / preferensi masyarakat), serta ketepatan (nilai guna dari program yang telah dijalankan).

Dalam bentuk model, integrasi program dalam penyelenggaraan kewenangan dekonsentrasi di Provinsi dapat digambarkan sebagai berikut. 


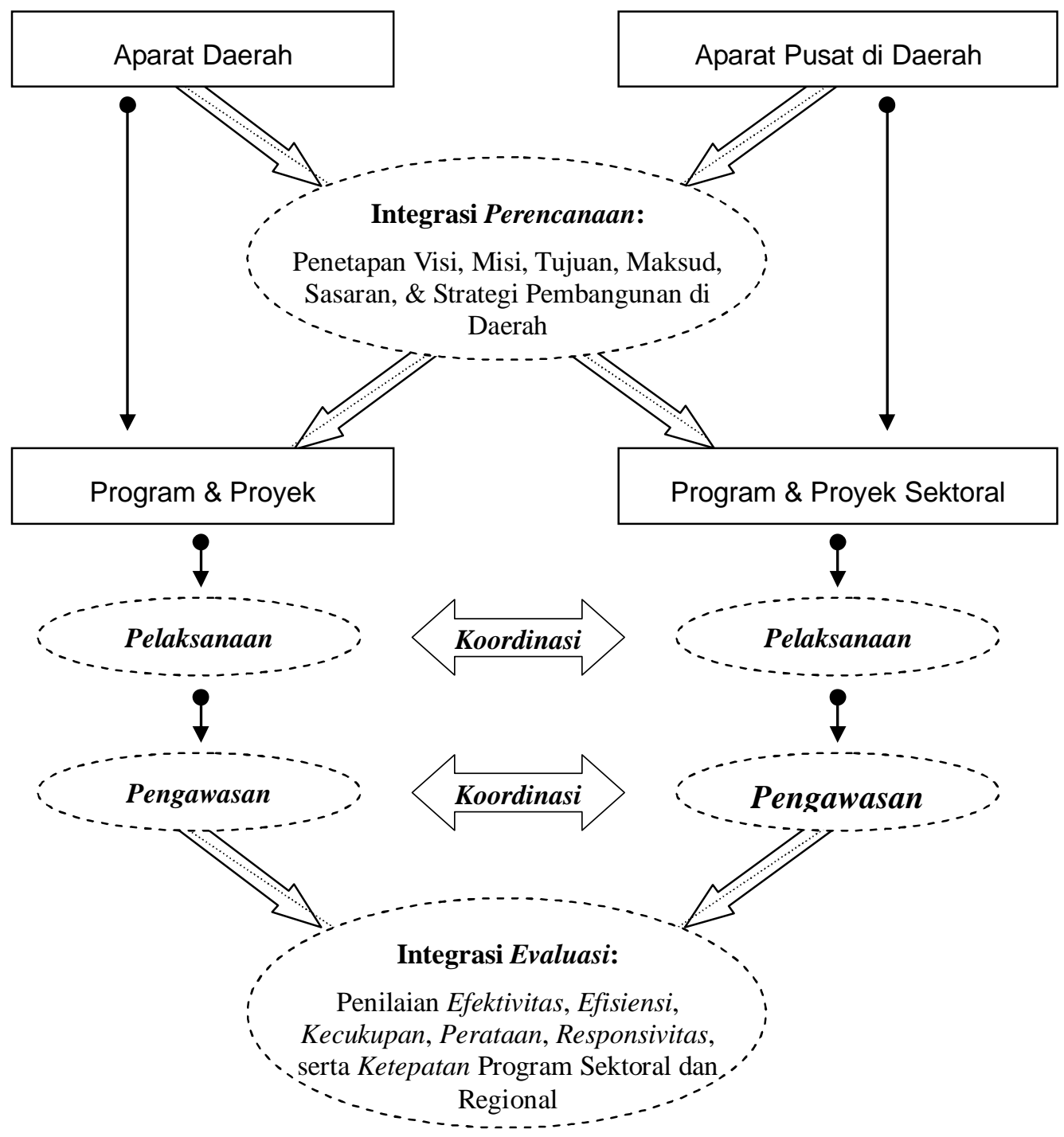

Gambar 3

Integrasi Program Dalam Penyelenggaraan Kewenangan Dekonsentrasi di Provinsi

\section{Penutup}

Sebagaimana ketentuan dalam UU Pemerintahan Daerah, dekonsentrasi merupakan salah satu prinsip penyelenggaraan pemerintahan yang tidak dapat diabaikan. Dekonsentrasi memiliki fungsi yang sangat strategis dalam rangka menegakkan Negara Kesatuan Republik Indonesia yaitu sebagai pengikat hubungan antara pusat dan daerah. Permasalahan yang selama ini melingkupi penyelenggaraan kewenangan dekonsentrasi harus mendapatkan perhatian yang serius oleh pemerintah sehingga tidak menjadi permasalahan yang berkepanjangan yang pada gilirannya malah akan mengaburkan makna pentingnya dekonsentrasi dalam NKRI. Dengan ditetapkannya PP Nomor 7 Tahun 2008 tentang Dekonsentrasi dan Tugas Pembantuan, bisa jadi akan membuat penyelenggaraan kewenangan dekonsentrasi menjadi lebih baik. Namun demikian, berkaca pada berbagai permasalahan yang selama ini terjadi dalam penyelenggaraan dekonsentrasi akan menimbulkan pertanyaan, apakah PP ini mampu mengatasinya?. Lepas dari hal tersebut, pengawalan, kontrol, dan monitoring mulai dari perencanaan, pelaksanaan serta pertanggungjawaban menjadi salah satu kunci keberhasilan penyelenggaraan dekonsentrasi, disamping itu faktor penting lainnya adalah adanya kebijakan yang mengintegrasikan fungsi, institusi dan program dalam penyelenggaraan kewenangan ini.

\section{Daftar Pustaka}

Buku, Laporan dan Tulisan 
BPK, 2005, Laporan Hasil Pemeriksaan Atas Laporan Keuangan Pemerintah Pusat Tahun 2005 - Laporan Sistem Pengendalian Intern Dan Kepatuhan Terhadap Peraturan Perundang-Undangan ,2006, Hasil Laporan Kepatuhan-LKPP 2006

, 2007, Pokok-pokok Ikhtisar Hasil Pemeriksaan BPK Semester I Tahun 2007

Cheema G. Shabbir \& Dennis A. Rondinelli, Decentralization and Development Policy Implementation in Developping Countries, Beverly Hills/London/New Delhi: Sage Publications, 1983.

Departemen Sosial, 2007, Pengelolaan Anggaran di Lingkungan Departemen Sosial

Kausar AS, 2005, Memantapkan Peran Gubernur Sebagai Wakil Pemerintah Di Daerah

Kepriprov.go.id. Rakor Dekonsentrasi dan Tugas Pembantuan Sektor di Provinsi Kepri, 3 Juni 2007

Kompas, 2007, Akuntabilitas Dana dekonsentrasi Lemah.

Mark Turner, 2002, Public Administration and Development Journal, No. 22, www.interscience.wiley.com

Schiavo-Campo dan Sundaram, 2000, To Serve and To Preserve: Improving Public Administration In A Competitive World,

Stroink, FAM, Mr.,2006, Pemahaman Tentang Dekonsentrasi (terjemahan), refika aditama, Jakarta

TempoInteraktif.com, Daerah Wajib Laporkan Dana Dekonsentarsi, 12 Februari 2007.

Wordpress.com, 2007, Dana Dekonsentrasi Bakal Diaudit, 1 Januari 2007 2007, BPK Khawatir terjadi Asset Laundering, 29 Januari 2007

www.kominfo.com. Menkeu : Alokasi DAU masih belum Optimal, 5 April 2006

\section{Peraturan Perundang-undangan}

UU Nomor 17 Tahun 2003 tentang Pengelolaan Keuangan Negara

UU Nomor 32 Tahun 2004 tentang Pemerintahan Daerah

UU Nomor 33 Tahun 2004 tentang Perimbangan Keuangan antara Pusat dan Daerah

PP Nomor 39 Tahun 2001 tentang Penyelenggaraan Dekonsentrasi

PP Nomor 106 Tahun 2000 tentang Pengelolaan Dan Pertanggungjawaban Keuangan dalam Pelaksanaan Dekonsentrasi dan Tugas Pembantuan.

PP No. 21 Tahun 2004 Tentang Rencana Kerja Dan Anggaran Kementerian/Lembaga (RKA$\mathrm{KL})$

PP Nomor 56 Tahun 2005 tentang Sistem Informasi Keuangan Daerah

PP Nomor 7 Tahun 2008 tentang Dekonsentrasi dan Tugas Pembantuan

Keputusan Menteri Keuangan Republik Indonesia No. 523/KMK.03/2000 tentang Tatacara Penganggaran, Penyaluran Dana, Pertanggungjawaban dan Pelaporan Pelaksanaan Dekonsentrasi dan Tugas Pembantuan

Peraturan Menteri Keuangan Nomor 46 / PMK.02 / 2006 tentang Tata Cara Penyampaian Informasi Keuangan Daerah 